IRSH 47 (2002), pp. 87-I I I DOI: I0.10I7/S0020859002000792

(C) 2002 Internationaal Instituut voor Sociale Geschiedenis

\title{
Betterment without Airs: Social, Cultural, and Political Consequences of De-industrialization in the Ruhr
}

\author{
STEFAN GOCH
}

At one time, the region of the Ruhr ${ }^{\mathrm{I}}$ was one of the most important areas for coal, iron, and steel production in Europe. This is no longer the case. The once abundant production of coal and steel found in this region is steadily dwindling, and what remains of the industry can fairly be considered antiquated. ${ }^{2}$ On the whole, the region has already undergone economic structural change, although some problems connected with it still need to be resolved. A few abandoned industrial areas need to be redeveloped and not all economic structures in the region are trendsetting; there are deficits in the infrastructure, such as in the transportation system; and the level of unemployment is clearly above the average of the Federal Republic of Germany (FRG) and of the Land North RhineWestphalia (NRW). In light of the degree to which industrial jobs have been lost, the region has survived structural change better than other old industrial regions, albeit with an obvious variation in the rate of success within the region.

Iron and steel regions like that of the Ruhr also once exhibited distinct

I. The Ruhr region is understood here to be the area of the Kommunalverbandes Ruhrgebiet [hereafter, KVR: Communal Association of the Ruhr]. This includes the district cities of Bochum, Bottrop, Dortmund, Duisburg, Essen, Gelsenkirchen, Hagen, Hamm, Herne, Mülheim an der Ruhr, Oberhausen and the districts Ennepe-Ruhr, Recklinghausen, Unna and Wesel. In this region of 52 independent communities with an area of 4,433 square kilometres approximately 5.3 million people currently live. For a history of this regional institution in the otherwise administratively rather fractured region, see Andreas Benedict, $80 \mathrm{Jabre} \mathrm{im} \mathrm{Dienste}$ des Rubrgebiets: Siedlungsverband Rubrkoblenbezirk (SVR) und Kommunalverband Rubrgebiet (KVR) im historischen Überblick 1920-2000 (Essen, 2000).

2. See my evaluation of structural change in the Ruhr as a success story, with several exceptions naturally: Stefan Goch, "Strukturwandel im Ruhrgebiet: Eine Erfolgsgeschichte?", Mitteilungsblatt des Instituts zur Erforschung der europäischen Arbeiterbewegung, 22 (1999), pp. I 59- I90; appearing earlier, idem, "Politik zur ökonomischen, sozialen und ökologischen Bewältigung des Strukturwandels im Ruhrgebiet: Ein Überblick", in Rainer Bovermann et al. (eds), Das Rubrgebiet - ein starkes Stück Nordrhein-Westfalen: Politik in der Region 1946-1996 (Essen, 1996), pp. 380-426; and Stefan Goch, "Strukturpolitik als Lernprozeß", in Karsten Rudolph et al. (eds), Reform an Rhein und Rubr: Nordrhein-Westfalens Weg ins 2I. Jabrhundert (Bonn, 2000), pp. 26-35. My most recent and extensive work on this topic is: Stefan Goch, Eine Region im Kampf mit dem Strukturwandel: Strukturpolitik und Bewältigung von Strukturwandel im Rubrgebiet (Essen, 200I). 
social and political-cultural characteristics: a labour force with an exceptionally high degree of relative homogeneity, middle and upper classes that were complementarily small, a close connection between the areas of production and reproduction, an authoritarian factory structure that extended even into leisure activities, male dominance, a modest degree of employment among women that represented nearly the opposite of large rural families, poor educational opportunities in an insufficiently urbanized environment, a sharp distinction by the masses of workers from "the bigwigs upstairs" including the white-collar employees, and a relatively intensive degree of state intervention based on the importance attributed traditionally to mining and later also to the new heavy industries.

What impact did the economic structural change have on social and political-cultural structures in the region, on the attitudes and behaviour of people in an area that had been previously influenced overwhelmingly by the coal, iron, and steel industry? And did an (endogenous) potential exist among regional actors and in the regional political culture that would enable the region and its inhabitants to experience a relatively peaceful and successful structural change with only a small amount of social friction instead of decline, was this a slow (re-)ascent, albeit not a soaring flight?

Whereas the economic dimensions of structural change were constantly discussed, certain other dimensions only became evident with time, needed more time to be even recognized, and are now being rather hesitantly addressed in social-history research. These were the social and cultural, particularly political-cultural, dimensions that arose with de-industrialization, the change and diversification of the economic structure, the emergence of service industries, the production of knowledge, and the accompanying pluralization of the working world and life in general. This explains why to date there are no long-term studies on the social structure of the Ruhr ${ }^{3}$ that extend to the present day, just as there are, for example, none on the history of education in the region - where opportunities to attend advanced institutions of learning only became available to the public at large during the I960s - or studies on individual professions and occupational groups. Against the backdrop of the special political influence that social democracy has had on the Ruhr for decades, important research findings on the region's political culture have been presented that

3. One exception is Klaus Tenfelde, "Soziale Schichtung: Klassenbildung und Konfliktlagen im Ruhrgebiet", in Wolfgang Köllmann et al. (eds), Das Rubrgebiet im Industriezeitalter: Geschichte und Entwicklung, 2 vols (Düsseldorf, 1990), vol. I, pp. I21-217. Also, Klaus Tenfelde, "Gesellschaft im Wohlfahrtsstaat - Schichten, Klassen und Konflikte”, in Karl Teppe et al. (eds), so Jahre Nordrbein-Westfalen: Land im Wandel (Münster, 1997), pp. 23-42; Klaus Tenfelde, "Das Ruhrgebiet und Nordrhein-Westfalen: Das Land und die Industrieregion im Strukturwandel der Nachkriegszeit", in Jan-Pieter Barbian et al. (eds), Die Entdeckung des Ruhrgebiets: Das Rubrgebiet in Nordrhein-Westfalen 1946-I996 (Essen, I997), pp. 28-38. 
begin to examine social change. ${ }^{4}$ Although the initial studies in the contemporary history of the Federal Republic as a whole were in political history, research has now begun to turn more attention to its social history. ${ }^{5}$

Because the scope of such research is still rather limited, it is only possible at this point to present the important developmental trends in the social and political culture of the Ruhr that have occurred as a result of structural change. What has become clear is that the Ruhr - which was once a region dominated by the coal, iron, and steel industry and now, after roughly forty years of structural change, a "completely normal" region featuring a range of industries and services - still has its particularities, that the people in the region will long be affected by their historical experiences, and that the experiences of change and of adaptation to it will continue to influence the region and its people.

\section{THE DIMENSIONS OF ECONOMIC STRUCTURAL CHANGE IN THE RUHR REGION}

As the heartland of heavy industry in West Germany, North RhineWestphalia generated 40 per cent of the industrial production in the Federal Republic in I95 I, even though production levels had not yet reached those prior to the Second World War because of extensive destruction, the lack of permits, or the dismantling of factories. Ninety per cent of the coal mined and 80 per cent of the iron and steel produced in the Federal Republic came from NRW. Whereas about 35 per cent of the labour force in West Germany as a whole were employed in crafts and industry in 1950, the figure equalled about 50 per cent in the Ruhr region. With regard to its social structure, the Ruhr was "the" proletarian region of the Federal Republic, since 66 per cent of its labour force were workers as opposed to the national average of 50 per cent (white-collar employees: 22 to 23 per cent). ${ }^{6}$

4. For a survey of the political development, see Bovermann et al., Das Ruhrgebiet; especially on the history of economic development, see Köllmann et al., Das Rubrgebiet im Industriezeitalter. 5. See this research report: Stefan Goch, "Deutschlands Erfolgsweg? Forschungsbericht zu neueren Darstellungen der Entwicklung der Bundesrepublik Deutschland", Archiv für Sozialgeschichte, 4I (200I), pp. 633-662.

6. Werner Plumpe, "Das 'Arbeitshaus' des neuen Staates? Die wirtschaftliche und wirtschaftspolitische Bedeutung Nordrhein-Westfalens für die Bundesrepublik zwischen 1946 und 1955", in Landeszentrale für politische Bildung Nordrhein-Westfalen (ed.), Der schwierige Weg zur Demokratie: Die Bundesrepublik vor 40 Jahren (Düsseldorf, 1990), p. 253; Anselm Faust, "Das Schwungrad des Wiederaufbaus: Die Wirtschaft an Rhein und Ruhr", in NordrheinWestfälisches Hauptstaatsarchiv (ed.), Nordrhein-Westfalen: Kernland der Bundesrepublik (Siegburg, I989), pp. 95f. A general account is found in Walther Däbritz, "Das Ruhrgebiet: Geschichtliche Tatsachen und Gegenwartsprobleme”, in Institut für Raumordnung (ed.), Ordnung und Planung im Rubr-Raum: Tatsachen und Aufgaben (Dortmund, I95 I), pp. I I-2 I. 
When the first short-time shifts occurred in Ruhr mining on 22 February I958, there were I 36 mines in operation that employed 488,94I people. Forty years later, in I998, only I 3 mines existed, providing about 60,000 jobs.7 In the iron industry of North Rhine-Westphalia, the number of jobs, most of which were located in the Ruhr, sank from 219,000 in 1958 to I 54,000 in 1987 and, following another round of drastic job cuts, dropped to 85,000 in I 994. Currently the figure is $60,000 .{ }^{8}$ The loss of jobs in the core operations of the coal and steel industry was accompanied by a simultaneous loss in dependent branches of industry. In NRW, producing industries lost I.5 million jobs between I96I and I987, and since then another 500,000 jobs have disappeared. ${ }^{9}$ Despite this, the Ruhr generally kept pace with NRW and FRG trends in the rate of registered unemployment after the crisis of the coal, iron, and steel industry began. However, the actual level of unemployment was always higher. Economic crises hit harder and lasted longer in the coal-mining region. Therefore, the labour-exchange districts of the Ruhr always topped the unemployment statistics, although their figures deviated considerably from one another once West Germany's "economic miracle" finally ended around $1974 .{ }^{10}$

The Ruhr not only suffered from the shrinking of a major sector of industry, but also from the fact that the entire structure of production, as had developed over time, was being effected by structural change. Already in the I950s, production growth lagged behind that of the Federal Republic as a whole. This can be attributed to the rebuilding of the traditional industrial structure of the Ruhr and its relative weak growth during the reconstruction period after the Second World War, whereas other regions

7. Joachim Huske, Die Steinkoblenzechen im Rubrrevier: Daten und Fakten von den Anfängen bis 1997 (Bochum, 1998), 2nd edn, pp. 34ff.; and current information of the RAG.

8. Ministerium für Wirtschaft, Mittelstand und Technologie des Landes Nordrhein-Westfalen [hereafter, MWMT], Bericht der Kommission Montanregionen des Landes Nordrhein-Westfalen (Düsseldorf, 1989), pp. 238f., 246ff.; NRW-Lexikon: Politik, Gesellschaft, Wirtschaft, Recht, Kultur (Opladen, 1996), pp. 23, 55, 255, 26I.

9. MWMT, Bericht der Kommission Montanregionen, pp. 238f., 246ff.; Wolfgang Köllmann et al., "Bevölkerungsgeschichte", in Köllmann, Das Rubrgebiet im Industriezeitalter, vol. I, p. I9I; Rolf G. Heinze et al., "Entwicklungen und Perspektiven industrieller Produktion in NordrheinWestfalen", in Rolf G. Heinze et al., Strukturwandel und Strukturpolitik in NordrheinWestfalen: Entwicklungstends und Forschungsperspektiven (Opladen, 1992), p. 40; Dietmar Petzina, "Zwischen Neuordnung und Krise: Zur Entwicklung der Eisen- und Stahlindustrie im Ruhrgebiet seit dem Zweiten Weltkrieg", in Ottfried Dascher et al. (eds), Die Eisen- und Stablindustrie im Dortmunder Raum: Wirtschaftliche Entwicklung, soziale Strukturen und technologischer Wandel im 19. und 20. Jabrhundert (Dortmund, I992), p. 540; Dietmar Petzina, "Wirtschaft und Arbeit im Ruhrgebiet 1945 bis 1985", in Köllmann, Das Rubrgebiet im Industriezeitalter, vol. I, p. 539. See Karl Lauschke, Schwarze Fabnen an der Rubr: Die Politik der IG Bergbau und Energie wäbrend der Koblekrise 1958-1968 (Marburg, 1984), p. 2; NRWLexikon, pp. 23, 55, 255, 261.

ı. See Andreas Gallas, "Arbeitsmarktpolitik im Ruhrgebiet", in Bovermann et al., Das Rubrgebiet, pp. $428 \mathrm{f}$. 
Table I. Breakdown by economic sector in \% of those employed and unemployment rates.

\begin{tabular}{|c|c|c|c|c|c|c|c|c|c|c|c|c|}
\hline & \multicolumn{3}{|c|}{ Agriculture and forestry } & \multicolumn{3}{|c|}{ Producing sector } & \multicolumn{3}{|c|}{ Service sector } & \multicolumn{3}{|c|}{ Unemployment rate } \\
\hline & KVR & NRW & FRG & KVR & NRW & FRG & KVR & NRW & FRG & KVR & NRW & $\begin{array}{l}\text { FRG } \\
\text { West }\end{array}$ \\
\hline 1950 & 4.5 & 11.7 & 23.3 & 63.4 & 55.1 & 43.3 & 32.1 & 33.2 & 33.4 & & 4.8 & 10.3 \\
\hline 1961 & 2.4 & 6.4 & 13.6 & 61.3 & 56.4 & 47.6 & 36.3 & 37.2 & 38.8 & & 0.4 & 0.5 \\
\hline 1970 & 1.5 & 4.3 & 9.1 & 58.4 & 55.7 & 49.4 & 40 & 40.1 & 41.5 & 0.6 & 0.5 & 0.5 \\
\hline 1980 & 1.4 & 2.5 & 5.3 & 51.7 & 48.4 & 45.3 & 47 & 49.2 & 49.4 & 5.3 & 4.4 & 3.5 \\
\hline 1990 & 1.2 & 2.2 & 3.6 & 44.4 & 42.5 & 40.6 & 54.4 & 55.3 & 55.8 & 10.8 & 8.4 & 6.6 \\
\hline 2000 & 1.2 & 1.7 & 2.5 & 33.3 & 33.5 & 33.5 & 65.4 & 64.9 & 64.0 & 12.2 & 9.5 & 8.1 \\
\hline
\end{tabular}

Compiled according to the statistics on the cities and districts of the KVR and Statistical Yearbooks of NRW and FRG. Starting in I99I, the FRG is as given in the territorial survey from 3 October 1990.

Sources: Charge of KVR territory 1975. 
were experiencing a catch-up effect or surge of development at the time. The weak rate of growth was caused in turn by factors such as substitution processes and the diminishing demand for raw materials and production goods. The branches of industry responsible for the underdevelopment of the Ruhr in comparison with the average FRG (and the average NRW) development were also those that were either growing or maintaining their employment levels in other regions. Overall, the other branches in the region grew at a rate below the FRG level because of their connections to old industry. The differences in development between regions within the Federal Republic, particularly between the Ruhr and other regions were the fundamental result of parallel trends in development. The decline of the secondary sector merely hit the Ruhr, with its coal, iron, and steel industry and its other producing sectors, much harder. ${ }^{\text {II }}$

Structural change in the Ruhr was supported through an active structural and regional policy implemented at the various political levels (community, regional actors, NRW, federal, EU) but particularly at the NRW level. Whereas in 197058 per cent of those employed $(\mathrm{I}, 285,700)$ were still working in industrial production, 20 years later this figure was only 44 per cent $(963,500)$, while the share of those employed in the service sector rose from 40 per cent $(88 \mathrm{I}, \mathrm{I} 00)$ to 54 per cent $(\mathrm{I}, \mathrm{I} 80,600)$. Just in the I 980 alone, a total of 210,000 new jobs were created in the service sector. ${ }^{12}$ The sectoral structure of the region currently corresponds closely with that of the Federal Republic as a whole. Still, there are several cases where the Ruhr lags behind in the development of various economic sectors and branches, especially in the area of production-oriented and highly specialized (consulting) services. ${ }^{\mathrm{I}}$ With its relatively high rate of

I I. MWMT, Bericht der Kommission Montanregionen, p. 254. See the contributions in Willi Lamberts (ed.), Nordrhein-Westfalen in der Krise: Krise in Nordrhein-Westfalen (Berlin, 1985), pp. 7-37; Dietmar Petzina, “The Ruhr Area: Historical Development”, in Joachim Jens Hesse (ed.), Die Erneuerung alter Industrieregionen: Ökonomischer Strukturwandel und Regionalpolitik im internationalen Vergleich (Baden-Baden, I988), pp. 496ff.; Petzina, "Wirtschaft und Arbeit", pp. 544, 564f.; Rolf G. Heinze et al., "Industrial Clusters and the Governance of Change: Lessons from North Rhine-Westphalia (NRW)", in Hans-Joachim Braczyk et al. (eds), Regional Innovation Systems: The Role of Governance in a Globalized World (London, 1998), pp. 263ff.; Dieter Läpple, "Zwischen gestern und übermorgen: Das Ruhrgebiet - eine Industrieregion im Umbruch", in Rolf Kreibich et al. (eds), Bauplatz Zukunft: Dispute über die Entwicklung von Industrieregionen (Essen, 1994), pp. $37 \mathrm{ff}$.

I 2. KVR, Initiativkreis Ruhrgebiet (eds), The Rubr: The Driving Force of Germany - An Investors' Guide (Essen, I992), pp. 25 f.; Jürgen Aring et al., Krisenregion Ruhrgebiet? Alltag, Strukturwandel und Planung (Oldenburg, 1989), pp. 67f. Concerning these trends, see also MWMT (ed.), Strukturwandel in Nordrhein-Westfalen: Entwicklung und Perspektiven des Dienstleistungssektors (Düsseldorf, 1988), pp. 29 and 29-39 on the type of services.

I3. Empirical reference: KVR (ed.), Kleine und mittlere Betriebe im Ruhrgebiet: Bestand, Struktur und Entwicklung im Vergleich zu anderen westdeutschen Verdichtungsräumen zwischen den Jabren 1980 und 1993 (Essen, 1996), pp. 97-I I9. See Klaus Brake, Dienstleistungen und regionale Entwicklung: Eine empirische Untersuchung (Oldenburg, I993), pp. I I, 87f. 
unemployment, the Ruhr has become a "normal" area of agglomeration with regard to its economic structure - a place almost like any other. The Ruhr is no longer a monostructural region for the coal, iron, and steel industry; instead, it has become a highly diversified, and thereby less crisisprone, economic region with coal mining and steel production. New, important, and (according to all current evaluations) promising economic activities have been established there. Various networks of new production lines, products, and processes have arisen around the "old" industries of coal, iron and steel, chemicals, and energy. Throughout the process of structural change over the decades, the actors in the Ruhr have been repeatedly successful in mobilizing means used to cushion the resulting blows of economic change to the social structure. As a result, structural change has taken place with relatively little disruption, and no-one belonging to the core work force of Ruhr mining and the iron and steel industry has "landed on the street".

The most critical factor contributing to the success of the economic restructuring policy in and for the Ruhr region was an ability developed early in the process among all relevant actors to cooperate despite diverging interests, and especially to remain undeterred by the boundaries of institutional fragmentation in the political system. Whereas, on the one hand, large sums of public funds were appropriated for social cushions, and on the other the losses suffered by private business and the resulting damage in the region were subsidized by the government, local communities and the NRW government in particular overcame their limited avenues for action by mediating and organizing cooperation, by treating it almost as an immaterial resource. The political actors were benefited by the fact that the coal, iron, and steel industries had a long history of cooperation and tripartisanship, a history that included both the experience of failed cooperation in the Weimar Republic and of renewed cooperation in the era following the fall of National Socialism. In the unique situation of the early postwar period, codetermination ${ }^{14}$ was introduced as a special form of industrial relations to the coal, iron, and steel industry, which continued to develop into a specific culture of participation at factory, entrepreneurial, and regional levels. Various forms of cooperative or corporatist policy were the source of major procedural

I4. Gabriele Müller-List, Montanmitbestimmung, Das Gesetz über die Mitbestimmung der Arbeitnehmer in den Aufsichtsräten und Vorständen der Unternebmen des Bergbaus und der Eisen und Stabl erzengenden Industrie vom 2 I. Mai I95I (Düsseldorf, 1984); idem, Neubeginn bei Eisen und Stabl im Rubrgebiet, Die Beziehungen zwischen Arbeitgebern und Arbeitnehmern in der nordrhein-westfälischen Eisen- und Stahlindustrie 1945-1948 (Düsseldorf, 1990); Norbert Ranft, Vom Objekt zum Subjekt, Montanmitbestimmung, Sozialklima und Strukturwandel im Bergbau seit 1945 (Cologne, I988); Gloria Müller, Strukturwandel und Arbeitnehmerrechte, Die wirtschaftliche Mitbestimmung in der Eisen- und Stablindustrie 1945-1975 (Essen, 1991). 
innovation in structural policy efforts and involved numerous regional actors in coping with structural change. Not only did this achieve social peace, but to a limited degree diverging interests were articulated and considered, and common solutions to problems were worked out. ${ }^{\text {Is }}$ Despite the economic structural crisis, and with the help of social cushions for many, it was possible within this fabric of cooperation to weave together at least intergenerational structural change with processes of upward mobility.

\section{ADAPTATION TO DEMOGRAPHIC DEVELOPMENT}

Together with the economic structural change and particularly the disappearance of the structures inherent in the coal, iron, and steel industry, the old social configurations also faded. At first this meant adapting to the general demographic trends associated with the transition to a shrinking and ageing society, which were most evident in the disappearance of old family structures. Such major developmental trends included the increase of female employment, a drop in the marriage rate, decreasing numbers of children, and an increase in the divorce rate. In place of the poor prospects facing families dependent on the coal, iron, and steel industry, especially women, and families with large numbers of children, came some hope of prosperity with the advent of smaller families and the emergence of new forms of cohabitation and living alone. As early as the 1960s, the demographic constellation of the Ruhr matched that of the average big city with regard to population. ${ }^{16}$ Independent of regional influences, the number of children sank in concurrence with other general developmental trends, such as decreasing church membership, increased educational training, and the development of consumer society. As was common in big cities and metropolitan areas, a continuing diversity in private lifestyles followed on the heels of the demographic development, the general improvement of living standards also for employees, and the social diversification. ${ }^{17}$ The pluralization of lifestyles also in the Ruhr region, has become quite extensive, as is seen, for example, with regard to establishing a family:

It is no longer clear whether one marries, when one marries, whether one lives with someone and does not marry, marries and does not live with that person, whether one conceives or raises a child in or out of wedlock, with the person

I 5. Summarized in Goch, Eine Region, pp. 476-498.

I6. Tenfelde, "Soziale Schichtung", pp. I 54-167, I79; idem, "Das Ruhrgebiet", pp. 29ff. Also, idem, Die "neue Mitte" im Rubrgebiet: Sozialstruktur und Vergesellschaftung in der Nachkriegszeit, lecture for the Gesellschaft der Freunde der Ruhr-Universität Bochum e.V., I4 June 2000.

17. See for example the insightful essay by Ulrich Beck et al., Eigenes Leben: Ausflüge in die unbekannte Gesellschaft, in der wir leben (Munich, 1995). 
with whom one lives or with the person whom one loves but who lives with someone else, before or after having a career or in the midst of one. ${ }^{18}$

One residual characteristic of the region is the low percentage of homeowners compared with both the averages of North RhineWestphalia and the Federal Republic.

The decrease in the number of children per family and the vanishing of semi-open family structures, ${ }^{19}$ starting in the I920s, meant that families could pay greater attention to the welfare of their children. The improvement of living standards and several measures of the extended welfare state enabled more people to begin to plan their lives and to take advantage of the educational opportunities being offered. In turn, more people became upwardly mobile or at least could choose an occupation different from that of their parents.

\section{THE RISE OF THE NEW MIDDLE CLASSES IN THE RUHR}

Economic structural change and the changes in production processes linked to it were foremost responsible for the obvious changes that occurred in society, particularly in the social structures. While the percentage of workers in the labour force stagnated and then dwindled, the percentage of white-collar employees increased. ${ }^{20}$ Overall, in this formerly proletarian region, we see an expansion of the social groups that are rather imprecisely labelled the middle classes.

Originally, the size of bourgeoisie in the Ruhr was rather insubstantial. This region of coal, iron, and steel was dominated by heavy industry and its industrialists. What few middle-class groups existed were primarily involved in crafts, trade, or the poorly developed service sector that was dependent on industry or the working class. Furthermore, the demand for people in professions was rather limited. In the coal, iron, and steel industry, there was but a small middle-management group comprised of foremen and overseers. Until the phase of catch-up urbanization started in the I 920 s, there were also very few civil servants in the region. Following a verdict by the German emperor, no military forces were stationed in the

I8. Ulrich Beck, Risikogesellschaft: Auf dem Weg in eine andere Moderne (Frankfurt am Main, 1986), pp. I63f. Translated into English for this article.

19. Franz-Josef Brüggemeier et al., "Schlafgänger, Schnapskasinos und schwerindustrielle Kolonie: Aspekte der Arbeiterwohnungsfrage im Ruhrgebiet vor dem Ersten Weltkrieg”, in Jürgen Reulecke et al. (eds), Fabrik, Familie, Feierabend: Beiträge zur Sozialgeschichte des Alltags im Industriezeitalter (Wuppertal, 1978), pp. I39-172; Lutz Niethammer et al., "Wie wohnten Arbeiter im Kaiserreich?", Archiv für Sozialgeschichte, I6 (1976), pp. 6 I-I 34; Stephen H.F. Hickey, Workers in Imperial Germany: The Miners of the Rubr (Oxford, I985), pp. $48 \mathrm{ff}$. 20. Werner Plumpe, "Das Ende der Koloniezeit: Gedanken zur Sozial- und Wirtschaftsgeschichte des Ruhrgebietes in den soer und frühen 6oer Jahren", in Barbian et al., Die Entdeckung des Rubrgebiets, pp. I 53 f. 
Ruhr, which could have been incited by the working masses. Universities were also not planned for the working class, thus making academics and scholars a rarity in the region. ${ }^{2 \mathrm{I}}$

With economic structural change emerged a large salaried class. The employment structure changed in the wake of the regional restructuring, specifically the overall modernization of production processes, the increasing influence of the service sector as a whole, and the obvious expansion of government involvement in the I960s and I970s. In addition to the trend toward greater expansion of the public sector evident across the entire FRG, the Ruhr sought to catch up with the rest of the country, for example in communal administration, welfare institutions, and the entire educational system. Since the Ruhr is primarily administered "from outside", the region still lacks today other major administrative institutions, the jobs that these would provide, and consequently the labour force with the necessary qualifications and influences. On the whole, however, the number of white-collar employees grew rapidly in the old workingclass region. As early as 1970, the percentage of workers among the total employed population dropped below the so per cent mark. The share of professionals in the population reached a level typical for the rest of NRW, and in connection with the expansion of the educational system, the personnel of educational institutions constituted an important percentage of the growing middle classes. ${ }^{22}$

More women entered the workforce, and many but not all of them found white-collar jobs especially in the service sector. As a result, the below-average percentage of employed women slowly began to rise. With the advent of structural change, and to a degree in the early postwar period, jobs for women opened up, for example, in light industries, in the newly built plants for electronics, temporarily in the textile industry, and especially in the service sector. Often women first began to work in order to afford the amenities offered by a growing supply of consumer goods. At the same time, women were "discovered" as a reservoir of labour, particularly in the service sector. Employment offered women another type of access to life outside the realm of the family, which constituted nothing less than a cultural break with the patriarchal society of heavy

21. As a case study on change in the urban bourgeoisie, see Karin Schambach, Stadtbürgertum und industrieller Umbruch: Dortmund I780-I870 (Munich, I996). Also, e.g. Tenfelde, Die "nene Mitte". On the neglect of education in the region, see Kurt H. Biedenkopf, "25 Jahre RuhrUniversität: erfüllte und nichterfüllte Reformerwartungen”, in Burkhard Dietz et al. (eds), Universität und Politik: Festschrift zum 25-jäbrigen Bestehen der Rubr-Universität Bochum (Bochum, 1990), pp. 295f.; Rolf-Dieter Volmerig, "Hochschulen im Ruhrgebiet: Entwicklung Funktion - Transfer", in Heiner Dürr et al. (eds), Ernenerung des Rubrgebiets: Regionales Erbe und Gestaltung für die Zukunft (Paderborn, 1993), p. 94. See Ulrich von Alemann et al., Nordrhein-Westfalen: Ein Land entdeckt sich neu (Stuttgart, 2000), p. 200.

22. Tenfelde, "Soziale Schichtung", p. 176. Tenfelde, Die "nene Mitte", examined the number of medical doctors and of teachers in relation to the population of the Ruhr. 
industrial workers. ${ }^{23}$ Starting in the late I950s, the technical breakthroughs in household appliances and new eating habits introduced by the consumer society changed housework and made it possible for many more women to work, a development with far-reaching, as yet insufficiently studied consequences for both family life and society. ${ }^{24}$

Because these "new" employees very often originated from the working class, social distance in the industrial plants between workers and their supervisors did not develop to the degree it had in earlier times. As the old, authoritarian managers and white-collar workers of the coal, iron, and steel industry left the labour force, the working class as a whole became more skilled, and the previously small group of salaried employees grew correspondingly; the labour force became more homogeneous and the authoritarian style of management was replaced with more cooperative behaviour. ${ }^{25}$ While being rocked by major structural change economically, the region experienced less social distancing during the metamorphosis of its social structure because people in the region quickly learned that bluecollar workers and white-collar employees could only be successful in defending their interests in an jeopardized industrial region if they worked together. Many mining employees who were no longer members of a separate union turned to the nonpartisan industry-based union, just as did a similarly large number of employees in the iron and steel industry. ${ }^{26}$ This also contributed to the further diminishing of distancing. Since consensusoriented forms of structural policy were implemented to handle structural change in the region, a trend emerged among white-collar employees and

23. Ingrid N. Sommerkorn, "Die erwerbstätige Mutter in der Bundesrepublik: Einstellungsund Problemveränderungen”, in Rosemarie Nave-Herz (ed.), Wandel und Kontinuität der Familie in der Bundesrepublik Deutschland (Stuttgart, 1988), pp. I I 5-I44; Robert G. Moeller, Geschützte Mütter: Franen und Familien in der westdentschen Nachkriegspolitik (Munich, 1997). For a long-term trend, Tenfelde, "Soziale Schichtung”, p. I47.

24. Overall, however, the amount of housework has not actually diminished because standards have been raised, a point made by Wolfgang König, Geschichte der Konsumgesellschaft (Stuttgart, 1999), p. 244. See also Michael Wildt, Vom kleinen Wohlstand: Eine Konsumgeschichte der fünfziger Jahre (Munich, 1996), pp. $232 \mathrm{f}$.

25. See also Helmuth Trischler, "Partielle Modernisierung: Die betrieblichen Sozialbeziehungen im Ruhrbergbau zwischen Grubenmilitarismus und Human Relations”, in Matthias Frese et al. (eds), Politische Zäsuren und gesellschaftlicher Wandel im 20. Jahrbundert: Regionale und vergleichende Perspektiven (Paderborn, I996), pp. I68ff.

26. Emil Schrumpf, "Gewerkschaftsbildung und -politik im Bergbau (unter besonderer Berücksichtigung des Ruhrbergbaus”, (unpublished Ph.D. thesis, University of Bochum, I958), pp. 33 ff. See Lauschke, Schwarze Fahnen, p. I43; figures taken from Klaus Armingeon, Die Entwicklung des westdeutschen Gewerkschaften 1950-1985 (Frankfurt am Main etc., I988), pp. 170-I74. See Hans-Eckbert Treu, "Stabilität und Wandel in der organisatorischen Entwicklung der Gewerkschaften: Eine Studie über die organisatorische Entwicklung der Industriegewerkschaft Bergbau und Energie", (unpublished Ph.D. thesis, University of Erlangen, 1979), pp. 53, 74. On the influence of salaried employees in mining, which after I945 was at first still rather limited, see Helmuth Trischler, Steiger im deutschen Bergbau: Zur Sozialgeschichte der technischen Angestellten I8I5-1945 (Munich, 1988). 
workers alike to perceive themselves as a unified workforce, regardless of status, in order to be able to play a sufficiently powerful role in the tripartisanship typical for the coal, iron, and steel industry, to avoid being divided and conquered. Many individuals moved upward economically but did not soar socially; instead they continued to associate themselves with the great majority of salaried employees.

\section{UPWARD MOBILITY THROUGH EDUCATION}

The main avenue to social change in the changing industry was at first the differentiation taking place in each plant, in which a growing white-collar workforce emerged. When the long-neglected educational system of the Ruhr was expanded in the I960s, a new generation was given the opportunity to rise through the "floodgates" of education to the middle class within a generation. However, the children of "real" workers benefited from this relatively less than did the children of those workers who had advanced to salaried positions but remained loyal to the industrial working class.

The shortcomings of the educational infrastructure were spotted quickly, and reform was initiated as part of the policy designed to cope with structural change. Thus, a long-term, extremely successful facet of regional policy turned out to be the expansion and development of the educational system in the region. International comparisons had made it clear in the I960s that higher levels of participation in education and training were imperative. At the same time, emphasis was placed on increasing the educational levels of those classes and regions that had previously been so inadequately served, and there was much debate about equal opportunity in education. In the Ruhr, the argument of structural change was used to support this effort: by creating greater educational capacities, a more highly skilled and better qualified labour force would emerge over the long run, which in turn would make the region more adaptable to the process of structural change. In addition, the expansion of the educational system and of scientific capacities (particularly in the area of technological development) was seen as a factor both to stimulate economic growth and to enhance competitiveness. ${ }^{27}$

Consequently, the Ruhr received its own universities, particularly in the central Hellweg zone, in Bochum (founded in 1961, built 1964-1984, classes offered as of 1965) and in Dortmund (founded 1962, at first as a

27. Peter Hüttenberger, "Hochschul- und Wissenschaftspolitik", in Hans Boldt (ed.), Nordrhein-Westfalen und der Bund (Cologne, 1989), pp. 203f., 207ff.; Volmerig, "Hochschulen im Ruhrgebiet", p. 88; Bernd A. Rusinek, "Hochschulen", in NRW-Lexikon, pp. I zof.; Alemann et al., Nordrhein-Westfalen, pp. 200f.; NRW according to Burkhard Dietz, "Hochschulpolitik in Nordrhein-Westfalen und die Gründung der Ruhr-Universität Bochum”, in Dietz et al., Universität und Politik, pp. 56-67. 
technical university following a conflict with Bochum over location, opened 1968). As other comprehensive universities were established, the government sought also to create these as more occupationally-oriented educational institutions meant to integrate the tasks of several types of institutions of higher education including colleges, universities, and technological and pedagogical institutes. Between 1972 and 1974, comprehensive universities were established in Essen, Duisburg, and Hagen (as a correspondence university). In addition, the universities and other institutions of advanced training were to base their coursework on a strong scientific-methodological foundation, geared especially toward the needs of the job market. Such institutions were established in Bochum and Dortmund, for example. ${ }^{28}$ Not until 1992 did the northern Emscher region, long neglected with respect to an academic infrastructure, receive its own tertiary educational institution in the form of the technical college (Fachbochschule) in Gelsenkirchen. ${ }^{29}$ Currently, North Rhine-Westphalia, including the Ruhr region, constitutes one of the most concentrated areas of institutions of higher learning. About I60,000 students are enrolled at the universities in the Ruhr, approximately 500,000 in all of NRW. ${ }^{30}$

In conjunction with the founding of new universities and similar institutions, secondary schooling in the Ruhr, as in all of Germany, was expanded, although in the Ruhr it was first necessary to also make up for the huge deficiency in pupils. Still in 1965 , when there was an average of sixty-two inhabitants for every Gymnasium pupil in all of NRW, there were ninety-three inhabitants per pupil in Gelsenkirchen, ninety-one in the Recklinghausen district, and ninety-one in Wanne-Eickel. The cities in the Hellweg area, however, came closer to the NRW average. By the

28. Volmerig, "Hochschulen im Ruhrgebiet", pp. 87-107; Hüttenberger, "Hochschul- und Wissenschaftspolitik”, pp. 2 I off.; Werner Mayer, Bildungspotential für den wirtschaftlichen und sozialen Wandel: Die Entstehung des Hochschultyps "Fachhochschule" in Nordrhein-Westfalen 1965-1971 (Essen 1997); Franz-Josef Jelich, "Von der Industriegesellschaft zur Wissensgesellschaft: Bildung und Wissenschaft in Nordrhein-Westfalen", in Rudolph et al., Reform an Rhein, pp. $45 \mathrm{ff}$. as was recommended by the Wissenschaftsrat, the Council of Sciences and Humanities, see p. 48; Dietz, "Hochschulpolitik in Nordrhein-Westfalen", pp. 69-10I; Burkhard Dietz, "Eine Hochschule für das Revier: Die Gründung der Ruhr-Universität Bochum”, in Nordrhein-Westfälisches Hauptstaatsarchiv Düsseldorf (ed.), NordrheinWestfalen. Ein Land in seiner Geschichte. Aspekte und Konturen 1946-1996 (Münster, 1996), pp. 400-405. See Eberhard Wadischat, "Die Hochschulpolitik des Landes Nordrhein-Westfalen in den Jahren von 1948 bis 1968", (unpublished Ph.D. thesis, University of Düsseldorf, 1993); Rainer Stierand, Hochschulgründungen in Nordrhein-Westfalen: Prozeßanalyse einer "wirklichen" staatlichen Planung (Dortmund, 1983); Wolfgang Böttcher et al., "Bildung fürs Proletariat", in Peter Grafe et al. (eds), Der Lokomotive in voller Fahrt die Räder wechseln: Geschichte und Geschichten aus Nordrhein-Westfalen (Berlin etc., 1988), pp. I4Iff.

29. Volmerig, "Hochschulen im Ruhrgebiet", p. 91; Günter Strüder et al. (eds), Etappen des Hochschulstandortes Recklinghausen (Recklinghausen, I995).

30. Alemann et al., Nordrhein-Westfalen, p. 200; Volmerig, "Hochschulen im Ruhrgebiet", p. I06; Rusinek, "Hochschulen", p. I33. 
middle to late I980s, the region had achieved a density of secondary schools comparable to that of other major municipal areas and major cities and had reached a number of completed school diplomas comparable to the NRW average, although the northern Ruhr region continues still today to deviate clearly from this. ${ }^{31}$

The expansion of the education system has served to eradicate most of the deficiencies in education and training that once existed in the Ruhr. The Ruhr universities have succeeded in developing the educational potential of the region. The qualification patterns of the Ruhr population, particularly of people at an employable age, are similar to those of other highly populated metropolitan areas. Students comprise 2.98 per cent of the Ruhr population, whereas this figure is greater than the average number of students in the FRG population as a whole. Another group that has emerged here consists of university employees, who, together with their families, number several tens of thousands living in the Ruhr region. As a social group, people associated with the universities have an influence on the lifestyle and political culture that should not be underestimated. Some places even create a "campus scene" with their own places of communication, etc. It is, however, difficult to measure how greatly the students have influenced the region. In 1968, when in several cities throughout the Federal Republic students stormed the streets, offered what in the long run turned out to be some thought-provoking impulses, and exhibited alternative, convention-flouting forms of behaviour, the universities in the Ruhr were still being established and the student movements were correspondingly weak. ${ }^{32}$ The various youth cultures popularized by secondary school pupils and university students evolved only later in the major metropolitan areas of the Ruhr and never possessed the same intensity as elsewhere. ${ }^{33}$ Even outside the scope of student and youth movements, students in the Ruhr region appear to be "down-to-

3I. Between 1968 and 1978 alone, twenty-four new Realschulen and twenty-one new Gymnasiums were established in the Ruhr region. The majority of the new comprehensive schools in NRW were located in the Ruhr (1976: fifteen comprehensive schools). Petzina, "Wirtschaft und Arbeit", pp. 532, 556. Statistics taken from Reiner Eismann et al., "Sozioökonomische Daten zum IBA-Planungsraum”, in Rolf Kreibich et al. (eds), Bauplatz Zukunft, pp. 265ff., 277f. See Tenfelde, "Das Ruhrgebiet", pp. 34f.; idem, "Soziale Schichtung", p. I 80 .

32. For example, see Norbert Kozicki, Aufbruch im Revier: 1968 und die Folgen (Essen, 1993); Daniel Rieser, "Die Studentenbewegung an der Ruhr-Universität Bochum vom Wintersemester 1965/66 bis zum Sommersemester 197I", (unpublished Ph.D. thesis, University of Bochum, 1973); Daniel Rieser, "Ein 'APO-Opa' erzählt [...]: Die Bochumer Studentenbewegung”, in Wilfried Breyvogel et al. (eds), Land der Hoffnung - Land der Krise: Jugendkulturen im Ruhrgebiet 1900-1987 (Berlin [etc.], I987), pp. 218-225; Wilfried Breyvogel, "Die '68er' im Ruhrgebiet”, in Barbian et al., Die Entdeckung des Rubrgebiets, pp. 329-338.

33. Werner Helsper, "Vom verspäteten Aufbruch zum forcierten Ausbruch: Jugendliche Gegenkultur im Ruhrgebiet”, in Breyvogel et al., Land der Hoffnung, pp. 226-239. 
earth" individuals, who have not let their prospects of later becoming upwardly mobile go to their heads. The Ruhr universities are predominantly "commuter universities", that is, the students live in urban communities scattered throughout the Ruhr, drive to the university campuses for classes, but remain integrated in the daily life of their home towns and faced with the realities existing there.

With the coming of improved educational opportunities, a new, subtly diversified middle class evolved as part of the de-industrialization process within a society that until then had been shaped almost exclusively by coal, iron, and steel workers and their way of life. This new middle class created a new "bourgeoisie through training". As the "first-generation upwardly mobile" (and even in the second generation), the members of this new class still remained in many ways entrenched in their original milieu and linked to the region and the particularities characteristic to the way of life so heavily influenced by of the working class of the Ruhr; this was facilitated by the fact that structural change was being handled primarily with cooperative and consensus-oriented means and measures of social cushioning. The social history of the "first-generation upwardly mobile" has not been comprehensively examined. There are no studies on the history of the various occupational groups, and no research has been done on the degree to which the widely diversified salaried workforce is splitting up into subgroups, each tending to nurture its own "culture", or on the degree to which various "social milieus" 34 are evolving that share a set of common values and mentalities in addition to the same social status and position. The changes in West German society chipped away at and glossed over the differences in the way of life and behavioural norms specific to class, social group, or stratum. Just as this affected the workingclass society of the Ruhr, 35 so too was the bourgeois demeanour altered. The rapid rise in the number of salaried employees, the entry of many women into the workforce in (usually lower-level) white-collar jobs, and finally the loss of the exclusivity associated with a salaried position relativized the self-esteem of salaried employees and eroded bourgeois self-confidence; in other words, this helped bring about a "debourgeoisization", just as the process of upward mobility contributed to the "deproletarianization" of the working class. ${ }^{36}$

34. Sinus-Institut, Die Sinus-Milieus und ibre Anwendung (Heidelberg, I998); Michael Vester et al., Soziale Milieus im gesellschaftlichen Strukturwandel: Zwischen Integration und Ausgrenzung (Cologne, 1993).

35. With respect to the working class, for example, see Josef Mooser, Arbeiterleben in Deutschland 1900-1970 (Frankfurt am Main, 1984).

36. For example, see Josef Mooser, "Arbeiter, Angestellte und Frauen in der 'nivellierten Mittelstandsgesellschaft': Thesen", in Axel Schildt et al. (eds), Modernisierung im Wiederaufbau: Die westdeutsche Gesellschaft der soer Jabre (Berlin [etc.], I993), pp. 370 f. 


\section{SELF-ASSURANCE AND THE CULTURE OF MEMORY IN THE RUHR REGION}

Since many people belonging to the middle class in the Ruhr region see their own personal histories as a part of the history of structural change, they also seek self-assurance in the history of the region as a region of change. Such a specific culture of memory, as is evident in the kindling of interest in regional history and industrial culture, befits a middle class that evolved from the working class of the Ruhr. Within the framework of an increasing interest that started in the late I960s in the topic of regional studies and specifically in the history of the Ruhr region itself, work began on regional self-image and thereby also on regional awareness. Since the mid-I970s, there has been an outburst of research and consequently of literature on the Ruhr. ${ }^{37}$ Even though the number of scholarly works on the history of the Ruhr is still somewhat limited, these have a significant impact through popularized and currently nostalgic ("there's no place like home") publications, whereby the function of history is referred to "as a genuine element of every spatial and psychic 'location' of people"..$^{8}$

Since the I970s, the Ruhr has discovered the value of the material and architectural traditions of its industrial history, quite in contrast to its previously fast-paced attitude and general irreverence for tradition in this regard. Following the founding of the Museum technischer Kulturdenkmale (Museum of Technological Heritage) in 1975 in Hagen, the industrial museums of the Rhineland and of Westphalia began in 1979 to preserve characteristic industrial monuments and to present these in their original environment and function. The struggle to save factory settlements and historical buildings are also linked to these projects. Still today, architectural witnesses to the history of the Ruhr are being preserved at great expense as meaningful elements of identification among the people of the region and as an expression of regional political culture. In cooperation with the International Bauausstellung Emscherpark (1989-1999), restored industrial monuments found in many locations throughout the Emscher region were not turned into museums, but given new purposes including that of housing technology centres. As usually quite visible landmarks, these monuments embody and symbolize the region's past and present and

37. See Klaus Tenfelde, "Neue Mitte, neues Selbstbewußtsein", in Gerd Willamowski et al. (eds), Ruhrstadt: Die andere Metropole (Essen, 2000), pp.I 8ff.; Stefan Goch, "Stadtgeschichtsforschung im Ruhrgebiet: Ein Forschungs- und Literaturbericht”, Archiv für Sozialgeschichte, 34 (I994), pp. 44I-475; Karl Teppe, "Regionalismus und Regionalgeschichte: Zum Verhältnis von kulturpolitischen Interessen und regionalgeschichtlichen Konzeptionen am Beispiel Westfalen", Informationen zur Raumentwicklung, (1993), pp. 729-737.

38. Detlef Briesen et al., Regionalbewußtsein in Montanregionen im 19. und 20. Jabrhundert: Saarland, Siegerland, Rubrgebiet (Bochum, I994), p. 2 (quotation translated into English for this article). 
indeed the change itself as a structural element of regional political culture. 39

Since the new middle classes in the Ruhr did not possess any bourgeois cultural models or a traditional urbanity, they created specific cultural forms that are oriented particularly toward their experiences in mastering structural change. While these new and growing middle classes are busy evolving their own behavioural norms, attitudes, and ways of life, older influences and associations from both the small original bourgeois realm and the working-class milieu are disappearing in the diffuse heterogeneity of the new middle classes. Included in the barely definable middle classes of the Ruhr are the conventional urban bourgeoisie, the old and new selfemployed (as the equivalent to the old economic bourgeoisie) who remain rather few in number relative to other comparable regions, the academic professionals or those in correspondingly trained professions (as the educated social groups), the functional elite in local business, politics, and administration, and the educated groups from a wide diversity of occupations that are relatively new to the region. In this way, a social configuration has arisen out of the middle of society, one that hardly existed when the society of the Ruhr was dominated by the working class, mine owners, and magnates. Large numbers of the middle class share the experiences of upward mobility and of the search for individual alternatives to the milieu of their social background. Above all, they have in common the generation-specific experiences of the expansion of educational opportunity, of popular culture since the I960s and the new social movements, and a critical perspective on change, based on insight into the Janus-faced aspect of modernity..$^{\circ}$ In the Ruhr, which earlier was such a non-bourgeois region, it is the shared experience of upward mobility that links the middle classes best. This "first generation" to move into the middle classes has remained extremely sedentary and tied to the region; these people associate with pride their own experience in moving upwards with structural change and thereby cultivate the heritage of their industrial culture and a regional culture of memory. ${ }^{4 \mathrm{I}}$ Not only the brief history of the new middle classes and their ties to their social origins, but also the similarities in the lives of those making up the diversified middle classes, which are primarily salaried middle classes, prevents the degree of individualization from becoming all too great. Therefore, an employee

39. Andrea Höber et al. (eds), IndustrieKultur: Mythos und Moderne im Rubrgebiet (Essen, 1999); Henry Beierlorzer et al. (eds), SiedlungsKultur: Neue und alte Gartenstädte im Rubrgebiet (Braunschweig [etc.], 1999); Manfred Sack, 70 km Hoffnung: Die IBA Emscher Park (Frankfurt am Main, 1999).

40. See Tenfelde, Die "neue Mitte", pp. r6f.; Ulrich Heinemann, "Die neue soziale Mitte: Was sie prägt und wie man mit ihr Politik macht", in Rudolph et al., Reform an Rhein, pp. I7If.

4I. Heinemann, "Die neue soziale Mitte", p. I75. 
mentality can also continue to exist among the salaried middle classes even after upward mobility has been achieved.

\section{IN THE SHADOW OF SUCCESSFUL STRUCTURAL CHANGE}

Structural change and the entire development of so-called modern industrial society have not only led to processes of upward mobility; there have also been losers in the development of adapting the Ruhr region to the average structures of the Federal Republic. Economic migrants, especially from southeastern Europe, comprise in many cases a new underclass. Those hit particularly hard by unemployment are relatively unskilled workers from the producing industries, foreigners or those individuals who have migrated, and young people under the age of twentyfive. In the shadows of the modernized industrial and service economy and the salaried middle classes have evolved, especially in the north, "islands", quarters, city neighbourhoods, or even streets in which poverty and a culture of poverty have spread among the losers of modernization. This is where a potential of people gather, through a selective process of migration, who no longer have the means at their disposal to avoid the downward spiral of poverty. In particular, this is where we find one-parent families, minors, and migrants. With the aid of social services and a still existing capacity for self-help, it has been possible to prevent the development of slums, ${ }^{43}$ although distinct differences between the various city neighbourhoods are clearly identifiable in an analysis of social spaces. ${ }^{44}$ These groups of losers created by structural change, those marginalized by the job market, and others pushed to the periphery of urban society neither possess sufficient capabilities to organize themselves and articulate their interests, a lever of influence or veto power, nor are they able to come together as a group due to the extent of their heterogeneity. Therefore, they are not a great source of conflict and remain instead hidden in the shadows of society.

\section{CHANGE IN REGIONAL POLITICAL CULTURE}

Whereas underprivileged groups are able to exercise little influence on regional politics, the new middle classes also only shape politics to a limited degree; that is, they remain entrenched in the old, established

42. Hermann Bömer, Rubrgebietspolitik in der Krise: Kontroverse Konzepte aus Wirtschaft, Wissenschaft und Verbänden (Dortmund, 2000), pp. I35f. Studies are rare, but one example is on Duisburg-Bruckhausen by Gertrud Tobias et al. (eds), Von der Hand in den Mund: Armut und Armutsbewältigung in einer westdeutschen Großstadt (Essen, 1992).

43. Klaus Peter Strohmeier et al., "Sozialraum Ruhrgebiet: stadträumliche Differenzierungen von Lebenslagen, Armut und informelle Solidarpotentiale", in Bovermann et al., Das Rubrgebiet, pp. $45 \mathrm{I}-475$. 
political culture of the region. After World War II, the workers of heavy industry in the region made a lasting mark on the political culture. Whereas the development of the region following the liberation from National Socialism, as for most of its history, was primarily shaped by decisions made elsewhere, there emerged in the factories and in the local and communal governments of the cities and city districts of the Ruhr in the months immediately after the war ended a regional model of politics that has come to be known as basisnabe Stellvertretung (grassroots representation). This model incorporated old Social Democratic free-trade union traditions of participation politics and class compromise; the model was also influenced by the conditions present in the Ruhr region with its influential heavy industry and its corporatist structures. In this model, a Social Democratic elite was selected from among the functionaries of trade unions, communal politics, and the political party and assigned a major role in mediating between the lives of the workers and the economy, between politics and the entire society, without the workers having to be continually active themselves. The demise of older structures of solidarity made the model of politics based on acting representatives the only accepted concept of collective lobbying. Strengthened institutionally by the codetermination law passed for the coal, iron, and steel industry in the early postwar period, trade unionists and Social Democrats now articulated the emancipatory aims of the people of the Ruhr and their claims to justice and social security. Social democracy in the Ruhr and its trade-unionist and political functionaries and mandates came to embody the collective experiences of "ordinary people" working in the factories and living in the region's industrial communities. As their lobbyists, these representatives developed in the region a special "culture of the man in the street" that can be called the "reshaping of a sociopolitical milieu centred around trade unions, large factories, and communal institutions". ${ }^{44}$

44. Especially for the political model of grassroots representation, see Michael Zimmermann, "Basisnahe Stellvertretung: Zur sozialdemokratischen Dominanz im Ruhrgebiet", Revierkultur, 2 (1987), 2, pp. 46-53; idem, “Geh zu Hermann, der macht dat schon': Bergarbeiterinteressenvertretung im nördlichen Ruhrgebiet", in Lutz Niethammer (ed.), "Hinterher merkt man, daß es richtig war, daß es schief gegangen ist": Nachkriegserfabrungen im Rubrgebiet (Berlin, I983), pp. 277-3 I0; Alexander von Plato, "Nachkriegssieger: Sozialdemokratische Betriebsräte im Ruhrgebiet: Eine lebensgeschichtliche Untersuchung", in ibid., pp. 311-359; idem "Der Verlierer gebt nicht leer aus": Betriebsräte geben zu Protokoll (Berlin, 1984); Bernd Faulenbach, "Mitbestimmung und politische Kultur im Ruhrgebiet", in Helmut Martens et al. (eds), Mitbestimmung und Demokratisierung: Stand und Perspektiven der Forschung (Wiesbaden, 1989), pp. 216-228. For the quotation translated here into English, Karl Rohe, "Regionale (politische) Kultur: Ein sinnvolles Konzept für die Wahl- und Parteienforschung?", in Dieter Oberndörfer et al. (eds), Parteien und regionale politische Traditionen in der Bundesrepublik Deutschland (Berlin, 1991), p. 33. See Bernd Faulenbach, "Die Herausbildung eines neuen sozialdemokratischen Milieus nach dem Zweiten Weltkrieg", in Peter Friedemann et al. (eds), Struktureller Wandel und kulturelles Leben: Politische Kultur in Bochum I860-1990 (Essen, 1992), pp. 456f. on the emergence of a political milieu or a specific political style. 
Because the model of politics was geared toward the comprehensive cooperation of regional actors, it was possible to reconcile the anachronistic administrative and political fragmentation of regional institutions (Länder and federal government, communities, regions, communal associations, organizational boundaries, etc.).

The coal-mining crisis since 1958 and the job cutbacks in the coal, iron, and steel industry of the Ruhr strengthened the grassroots model of politics further because labour representatives and local politicians were the ones administering the social plans, meaning the diverse social measures to cushion the population from the consequences of structural change in the industry. Therefore, with the help of public subsidies, it was possible to carry out the job cutbacks in a manner that was, for the most part, socially just. ${ }^{45}$ The hopes of the workers in the Ruhr region for a comfortable life and protection from the consequences of the crisis in the coal, iron, and steel industry were fulfilled by the efforts of Social Democrats, the trade unions and their labour representatives. Overall, the demise of the coal, iron, and steel industry actually strengthened a political model based on cooperation and compensation: the conflicting interests of employers and employees and their organizations were dwarfed by the pressure of the economic crisis and by their common interest in cushioning the decline of the coal, iron, and steel industry. Therefore, it became relatively simple to agree on social cushions in the plants, mines, and factories. By creating in 1968 the united coal enterprise in the Ruhr, the Ruhrkohle AG, trade-union representatives were able to put a social net in place that prevented any Ruhr miner from falling into the deep crevices of economic insecurity. In the iron and steel industry, the employee councils and unions were also fairly successful in working out a socially acceptable plan for coping with structural change, although the negotiations on these measures was much more conflictual. Overall, a regional model of cooperation between management and labour, with the help of government, was at least able to guarantee social cushions against the repercussions structural change, which in other regions took place much more abruptly and brutally for those affected. In the Ruhr, a special regional culture of cooperation and consensus-building eventually developed out of structural change and was then strengthened. By fulfilling its demands for social compensation and cushions against the repercussions of structural change, the Social Democratic Party became the dominant political party. At the same time, the crisis produced a feeling of belonging

45. For more on the increased influence of the employee councils during the mine shutdowns, see also Lauschke, Schwarze Fabnen, p. I39. On the corresponding workers' consciousness, see Josef Esser et al., Krisenregulierung: Zur politischen Durchsetzung ökonomischer Zwänge (Frankfurt am Main, 1983), pp. 208-221. 
together, of camaraderie, and corporatist structures of consensus-seeking became the trademark of political behaviour in the Ruhr. ${ }^{6}$

The corporatist model of politics "rubbed off" on all of North RhineWestphalia. Against the backdrop of the successful social cushioning during the crisis created by structural change and in light of the corporatist mode of politics that integrates particularly the unions into the formation of policy, NRW is considered among the Länder to be the "social conscience" of the federal government. ${ }^{47}$ North Rhine-Westphalia earned this reputation in good part through the workers and their movements, particularly in the Ruhr region. A basic social consensus unites the industry-based union, some ranks of management, the social-Catholic wing of the workers associated in part with the Christian Democratic Union (CDU), and the SPD. ${ }^{8}$ The concepts on issues of social justice existing in the regional political culture were also influenced by a defensive mistrust of the "bigwigs upstairs", an employee-oriented corporatism, a fundamental predisposition toward solidarity and justice, a pronounced pragmatism, and personalized communication. ${ }^{49}$ In its role as the "social

46. See Bernd Faulenbach, "Merkmale und Entwicklungslinien der politischen Kultur des Ruhrgebiets", in Bovermann et al., Das Rubrgebiet, pp. $373 \mathrm{f}$.

47. This position follows a long tradition, also within the social-Catholic wing of the CDU. Minister President Karl Arnold (CDU) said in his inaugural speech on 21 September 1950, as criticism of the federal government led by Chancellor Konrad Adenauer and the liberal economic policy adopted by Bonn: "Das Land Nordrhein-Westfalen will und wird das soziale Gewissen der Bundesrepublik sein" ["North Rhine-Westphalia wants to be and will be the social conscience of the Federal Republic"]. Cited in Ursula Rombeck-Jaschinski, NordrheinWestfalen, die Rubr und Europa: Föderalismus und Europapolitik 1945-1955 (Essen, 1990), p. 85. See Rolf G. Heinze et al., "Gewerkschaften und Modernisierung der Wirtschaft: Langsamer Niedergang oder Flucht nach vorn”, in Dieter Schulte (ed.), Industriepolitik im Spagat (Cologne, 1995), p. 75 on the participation of the unions in structural policy in NRW (as opposed to other Länder). In Petzina, "Wirtschaft und Arbeit", p. 567, reference is made to the "vielfach bestätigte Fähigkeit zum sozialen Interessenausgleich zwischen Unternehmen und Gewerkschaften" ["frequently proven ability to achieve a social settlement between the companies and the unions”]. See Stefan Goch, “Der Ruhrgebietler': Überlegungen zur Entstehung und Entwicklung regionalen Bewußtseins im Ruhrgebiet”, Westfälische Forschungen, 47 (1997), pp. 6r 3 ff.

48. See Dietmar Petzina, “Das ‘soziale Gewissen' des Bundes: Nordrhein-Westfalen, Die Montan-Mitbestimmung und die neue Sozialpolitik”, in Landeszentrale für politische Bildung Nordrhein-Westfalen, Der schwierige Weg, pp. 265-278.

49. Karl Rohe, "Vom sozialdemokratischen Armenhaus zur Wagenburg der SPD: Politischer Strukturwandel in einer Industrieregion nach dem Zweiten Weltkrieg", Geschichte und Gesellschaft, I3 (1987), p. 53 I, speaks of the "Lebensweisen und Mentalitäten, den Sentiments und Ressentiments, dem Stolz und der Selbstachtung der kleinen Leute" ["ways of life and mentalities, the sentiments and resentments, the pride and self-respect of the ordinary people"], which social democracy reflected, although little ideological content is attributed to these. It is also forgotten that a part of the Ruhr culture still retains a dichotomous view of the world, transmitted through a grassroots elite, a view that distinguishes between the "man in the street" and the "bigwigs upstairs". Lutz Niethammer, "Normalisierung' im Westen: Erinnerungsspuren in die soer Jahre”, in Gerhard Brunn (ed.), Neuland: Nordrhein-Westfalen und seine Anfänge 
conscience", the region reflects an older influence through the nearly homogenous working and living conditions among the workers in the coal, iron, and steel industry, which in a social sense distinguished the Ruhr from other regions decades ago and was expressed in the self-image of the region with all of its working-class pride and its inferiority complexes. A political tradition that transcends all ideological camps and social strata is, in this context, the rather limited trust in the ability of free enterprise to direct the economy, although highly organized forms of control, particularly tripartisan ones, are viewed more positively. ${ }^{\circ}$

The corporatist influence has been passed onto the middle classes, which have become in many ways the co-supporters of processes of transformation, adaptation, and modernization. Social responsibility and at least an effort at pursuing a politics of cooperation and social partnership between labour and management comprise the central aspect of all attempts to cope with structural change, regardless of whatever alterations have been made in the strategies of structural policy. The continuing experience in coping with crisis has fused the region together and has enabled the development of a repeatedly proven ability to achieve social settlements. ${ }^{52}$ In all their efforts to provide a social cushion and to extend the timeframe of structural change, the various actors overall have - contrary to widely held beliefs - not fought structural change but attempted to shape and direct it. For the future wellbeing of the region, its most important capacities of development may well lie in its achieved diversity even economically, the variety of its structural policy projects and initiatives, the widespread participation of regional actors in coping with change, the incentive for consensus in the tripartisan model of politics, and the orientation toward self-stipulated social and ecological norms. These capacities will help the region to face whatever insecurity the future holds because they offer it various options and avenues of development. No longer will the region be dependent, for better or for worse, on a mono-industrial structure and a single avenue of development, as it was in earlier times.

As the region has prospered, the regional Social Democratic Party been transformed by social change. Not only have its voters improved their economic status, so have its members, functionaries, and elected officeholders. The party has become less of a people's party and more of a party of all people, meaning that it has attempted to integrate large

I945/46 (Essen, I986), p. 206, states that the "economic miracle" of postwar West Germany and the stabilization of the standard of living among the workers of the Ruhr created "keine Illusion einer klassenlosen Gesellschaft" ["no illusions of a classless society"].

50. Karl Rohe, "Politische Traditionen in Rheinland, in Westfalen und Lippe", in Landeszentrale für politische Bildung Nordrhein-Westfalen (ed.), Nordrhein-Westfalen: Eine politische Landeskunde (Cologne, I984), p. 29.

5 I. Petzina, "Wirtschaft und Arbeit", p. 567. See also Tenfelde, "Gesellschaft im Wohlfahrtsstaat”, p. 38 . 
segments of the gainfully employed population. 53 The political model, which has for so long been centred around the regional SPD, is now showing clear signs of age as change has progressed. It is becoming increasingly difficult to integrate the interests of a society that is continually diversifying as the economic and social structures are being transformed. The election results show that a growing amount of effort is needed in order to maintain the balancing act between various groups in the diversified population and that the party is finding itself more and more in strategic "Catch-22s" between the various interests and social groups. ${ }^{54}$ Furthermore, the political elite have, in many cases, lost touch with their constituency and tended to "raise themselves above the crowd", unlike a large number of their voters. They also have failed politically and morally in many places. The communal elections of September 1999 represented a major turning point for the party: the SPD lost significantly - albeit under extremely difficult conditions caused by national politics and the CDU won significantly, albeit with a very low voter turnout. The SPD lost its dominant position nearly everywhere in the region. The election results signal that the old political model centred around the Social Democrats and the unions has structurally come to an end. Although patterns of action geared toward consensus and cooperation are still effective, the continuing process of societal differentiation forces the actors involved to repeatedly adapt these to new problems that arise in organizing consensus in the region.

\section{CONCLUSION: IS THE RUHR A NEW MIDDLE-CLASS SOCIETY?}

Finally we must ask ourselves whether, with the emergence of the diversified new middle classes, a new social configuration with possibly a new political culture has arisen in the region that is shaping or will shape the Ruhr. Helmut Schelsky saw a "levelled middle-class society"

52. In this sense, the title of this article has been inspired by Bodo Hombach, "Aufsteigen ohne Abzuheben: Der Wandel der Mitgliedschaft der SPD in NRW", in Lutz Niethammer et al. (eds), "Die Menschen machen ibre Geschichte nicht aus freien Stücken, aber sie machen sie selbst": Einladung zu einer Geschichte des Volkes in NRW (Berlin, I984), pp. 226-234.

53. The political model of grassroots representation was also referred to as a "class-transcending lobby", "corruption" or "we-are-all-in-the-same-boat partnership" and "corporatist model of communication and action"; Ulrich Borsdorf (ed.), Feuer und Flamme: 200 Jabre Rubrgebiet: Katalog zur Ausstellung im Gasometer Oberhausen (Essen, 1994), p. I 8. Structural conservatism and a subsidy mentality are also attributed to the established structures. Examples of such "Catch-22s" are in Ulrich von Alemann et al., "Parteien im Prozeß der Modernisierung: Auf der Suche nach einem realistischen Bild der Partei”, in Ernst-Martin Walsken et al. (eds), Mitgliederpartei im Wandel: Veränderungen am Beispiel der NRW-SPD (Münster [etc.], I998), p. 2. 
approaching, ${ }^{54}$ one emerging from a combination of factors: the coming of increasing prosperity, the social processes of upward mobility, the social diversification following the elimination of parts of the old German elite by National Socialism and war, as well as the destruction of societal hierarchies also by the Nazis and the war. The last national parliamentary election campaign in Federal Republic was directly aimed at addressing a "New Middle"ss in the electorate, which was understood to be heterogeneous social groups consisting of highly qualified employees, managers, small and medium-sized businessmen, engineers, new entrepreneurs, and scholars and scientists. ${ }^{6}$

Empirically, the interpretation of the "New Middle" and that of the "levelled middle-class society" overlook the considerable degree of social inequality that continues to exist overall and the differentiation taking place within the middle social strata of the populace. Although salaried employees and civil servants comprise a numerical majority of those gainfully employed, a number which clearly exceeds that of workers even in the Ruhr, this "majority" is very heterogeneous and can hardly be jointly addressed as a "New Middle". Existing structures of inequality are also being underestimated. Contrary to the assumption that the "elevator effect" would improve living standards generally and make widely accessible those consumer goods, services, leisure activities, status symbols, etc. once quite socially exclusive, and contrary to the realization that old class differences and social status distinctions and thus the political-cultural identities linked to them have been worn away or have vanished in favour of greater social diversity, social inequalities remain. ${ }^{57}$ In other words, the coming of social diversification and pluralization and the evident improvement of living standards overall have not meant the

54. Helmut Schelsky, "Die Bedeutung des Schichtungsbegriffes für die Analyse der gegenwärtigen deutschen Gesellschaft", in Helmut Schelsky, Auf der Suche nach Wirklichkeit: Gesammelte Aufsätze (Düsseldorf etc., 1965), pp. 33 Iff. (from 1954). See also Paul Nolte, Die Ordnung der deutschen Gesellschaft: Selbstentwurf und Selbstbeschreibung im 20. Jabrbundert (Munich, 2000), pp. $352 \mathrm{ff}$.

55. Heinemann, "Die neue soziale Mitte", pp. I68f. See Roland Tichy, Ab in die Neue Mitte: Die Chancen der Globalisierung für eine deutsche Zukunftsgesellschaft (Hamburg, 1998).

56. However, it was speculated here that definite concepts of a natural and harmonious position, so to speak, at the centre of society are widely held precisely among the middle classes. See Nolte, Die Ordnung der deutschen Gesellschaft.

57. Rainer Geißler, "Kein Abschied von Klasse und Schicht: Ideologische Gefahren der deutschen Sozialstrukturanalyse”, Kölner Zeitschrift für Soziologie und Sozialpsychologie, 48 (1996), pp. 319-338. From a historical perspective, Hans-Ulrich Wehler, Deutsches Bürgertum nach 1945: Exitus oder Phönix aus der Asche? (Bochum, 200I), p. 20. Important for the argument on the wearing away of differences at the same time as the "elevator effect" is occurring is the work of Ulrich Beck, "Jenseits von Stand und Klasse?", in Reinhard Kreckel (ed.), Soziale Ungleichheiten (Göttingen, 1983), pp. 35-74, and especially Beck, Risikogesellschaft. See Peter A. Berger, Entstrukturierte Klassengesellschaft? Klassenbildung und Strukturen sozialer Ungleichheit im historischen Wandel (Opladen, 1986). 
eradication of an unequal distribution of opportunity available to realize one's goals and ambitions in life. The claim that everyone has benefited from the general prosperity also overlooks the class-specific differences present in the upwardly mobile movement. ${ }^{8}$ Recently, it has been determined that the ranks of the elite have become enormously stable, meaning more specifically that social mobility is abating. 59

Based on the development of the middle classes in the Ruhr region, it can hardly be determined whether in 1945 the German bourgeoisie experienced its demise or its revival. ${ }^{60}$ Despite all the continuity in the recruitment from the ranks of the bourgeoisie, the middle classes that were produced primarily by advanced education and training were indeed new and very diversified in the Ruhr. These new middle classes are still in the process of finding their own self-confidence and identity. The first and second generation of the upwardly mobile are just beginning to create their own traditions. During the process of catch-up modernization everywhere in the Ruhr, a white-collar labour force featuring special regional influences has evidently come into being that has remained relatively humble and "down-to-earth" despite the significant upwardly mobile processes and a considerably successful handling of structural change. The reasons for this lie in a regional political culture that is geared strongly toward consensus and cooperation. Therefore, social or sociocultural distance may well be relatively weaker in the Ruhr than in comparable regions and a "social conscience" may be more popular here than is in keeping with these neoliberal times. Indeed, part of the self-confidence of this region, once so dominated by heavy industry, may well be the memory of its developmental process, a memory held with personal pride by the people of the Ruhr.

58. Geißler, "Kein Abschied", p. 327.

59. Wehler, Deutsches Bürgertum nach 1945, summarized on p. 20; Michael Hartmann, Topmanager: Die Rekrutierung einer Elite (Frankfurt am Main, 1996); Dieter Ziegler (ed.), Großbürgertum und Unternehmer: Die deutsche Wirtschaftselite im 20. Jabrhundert (Göttingen, 2000).

60. Wehler, Deutsches Bürgertum nach 1945 . 